Tropical Journal of Pharmaceutical Research June 2017; 16 (6): 1231-1237

ISSN: $1596-5996$ (print); 1596-9827 (electronic)

(C) Pharmacotherapy Group, Faculty of Pharmacy, University of Benin, Benin City, 300001 Nigeria.

All rights reserved.

Available online at http://www.tjpr.org

Original Research Article

http://dx.doi.org/10.4314/tjpr.v16i6.4

\title{
7-Piperazinethylchrysin inhibits melanoma cell proliferation by targeting Mek 1/2 kinase activity
}

\author{
Ning Zeng ${ }^{1}$, Hong $\mathrm{Qiu}^{2}$, Xin $\mathrm{Lian}^{3}$, Yuping Ren ${ }^{1}, \mathrm{Yi} \mathrm{Xu}^{1}$, Yiping $\mathrm{Wu}^{1}$, Hongbo \\ Tang ${ }^{1}$ and Haiping Wang ${ }^{1 *}$ \\ ${ }^{1}$ Department of Plastic and Aesthetic Surgery, ${ }^{2}$ Department of Oncology, ${ }^{3}$ Department of Dermatology, Union Hospital, Tongji \\ Medical College, Huazhong University of Science and Technology, Wuhan, Hubei Province, 430030, China
}

*For correspondence: Email: wanghaiping7@hotmail.com; Tel/Fax: 0086-27-83663568

Revised accepted: 10 May 2017

\begin{abstract}
Purpose: To investigate the growth-inhibitory effect of 7-piperazinethylchrysin (PEC) on melanoma cell lines.

Methods: Cell viability was analyzed by trypan blue exclusion assays and the cell cycle by flow cytometry using ModFit LT software. Specifically, cells were stained with propidium iodide $(0.5 \mathrm{mg} / \mathrm{mL})$ supplemented with RNase $A(50 \mathrm{mg} / \mathrm{mL})$, and analyzed using flow cytometry and ModFit LT software. Results: In A375 and B16F10 cell cultures, proliferation was reduced to 79 and $72 \%$, respectively, on treatment with $30 \mu \mathrm{M}$ PEC. PEC increased the proportion of A375 cells in G1/G0 phase to $71.23 \%$, versus $42.76 \%$ in untreated cells. In B16F10 and A375 cells, treatment with PEC caused the inhibition of Mek 1/2 kinase activity and suppressed Erk 1/2 phosphorylation. The level of cAMP-response element binding protein was increased by PEC. The expression of microphthalmia-linked transcription factor was also increased by PEC treatment. Marked enhancement was observed in the level of tyrosinase in melanoma cells on treatment with PEC. Analysis of PBG-D expression showed a marked increase in B16F10 and A375 cells on the addition of PEC to cell cultures at $72 \mathrm{~h}$. The level of PBG D expression was increased by 9- and 8.5-fold in B16F10 and A375 cells, respectively, on incubation with $30 \mu M$ PEC. The addition of a Mek 1/2 inhibitor (U0126) to the cultures promoted PEC-mediated growth inhibition.
\end{abstract}

Conclusion: PEC inhibited melanoma cell proliferation, apparently by blocking the cell cycle at G0/G1 and downregulating the Ras/Raf/Mek/Erk pathway.

Keywords: Tyrosinase, Kinase, Microphthalmia, Phosphorylation, 7-Piperazinethylchrysin

Tropical Journal of Pharmaceutical Research is indexed by Science Citation Index (SciSearch), Scopus, International Pharmaceutical Abstract, Chemical Abstracts, Embase, Index Copernicus, EBSCO, African Index Medicus, JournalSeek, Journal Citation Reports/Science Edition, Directory of Open Access Journals (DOAJ), African Journal Online, Bioline International, Open-J-Gate and Pharmacy Abstracts

\section{INTRODUCTION}

Human melanoma is one of the most commonly detected malignant cancers of the skin, and its incidence is increasing worldwide [1]. Melanoma is detected mainly in females in the age group of $25-29$ years [2]. The average survival period for patients suffering from the metastatic stage of melanoma is only 7 months $[3,4]$. Currently, the primary treatment for melanoma consists of surgery [3,4]. The use of chemotherapeutic agents is limited because of the development of drug resistance [5].

Many skin problems, including the formation of wrinkles and appearance of dark spots, can be treated successfully by the application of natural products [6,7]. Thus, natural products may also offer novel therapeutic agents for the effective treatment of melanoma. 
Flavonoids are an abundant class of natural products in plants, and biological investigations have revealed their promising potential as anticancer agents [8]. Studies have demonstrated that flavonoids exhibit inhibitory effects, both in vitro and in vivo, on tumor cell proliferation in various types of cancers, including prostate, breast, and hepatic cancer cells [9].

An important advantage of flavonoids is their low toxicity in living systems. Thus, flavonoids are important candidates for the treatment of cancer.

5, 7-Dihydroxyflavone, commonly known as chrysin, is a flavonoid isolated from extracts of many plants, including Passiflora caerulea, and propolis [10]. The biological properties of chrysin include anti-inflammatory, anti-oxidant, and anticancer activities [11]. In cervical cancer and leukemia cells, chrysin treatment causes the induction of apoptosis [12]. In vivo studies have shown that chrysin prevents carcinoma metastasis by inhibiting tumor angiogenesis [13].

A derivative of chrysin, 7-piperazinethylchrysin (PEC), is a potent anti-cancer agent against various carcinoma cell lines [14]. The current study was designed to investigate the effects of PEC on melanoma cells and its mechanism of action.

\section{EXPERIMENTAL}

\section{Reagents and test compound}

PEC was synthesized according to Edward et al [15]. The compound was dissolved in methanol to prepare a stock solution, which was diluted to provide solutions of the desired concentration. A specific inhibitor of Mek 1/2, U0126, was purchased from Sigma-Aldrich (St. Louis, MO, USA).

\section{Cell lines and culture conditions}

The murine B16F1 melanoma cell line was purchased from the National Center for Cell Sciences; the A375 human melanoma cell line was obtained from the American Type Culture Collection (Manassas, VA, USA). Both lines were cultured in RPMI-1640 medium supplemented with $10 \%$ fetal bovine serum. Cell culture was performed at $37{ }^{\circ} \mathrm{C}$ in a humidified atmosphere consisting of $5 \% \mathrm{CO}_{2}$ and $95 \%$ air.

\section{Evaluation of cell viability}

A375 and B16F10 cells were grown in 24-well plates at a density of $2 \times 10^{5}$ cells per well and cultured for $24 \mathrm{~h}$. Following culture, various concentrations of PEC, solvent, a combination of PEC and U0126, or U0126 were added to the wells, and the plates were incubated for $72 \mathrm{~h}$. After incubation, the cells were washed, harvested, and subsequently subjected to trypsinization. Trypan blue solution $(0.4 \%)$ was then added to the wells followed by an examination of the cells under an optical microscope. The effects of PEC and U0126 on cell viability were compared with control cells treated with solvent alone.

\section{Cell cycle analysis}

The cells were distributed in 6 -well plates at $3 \times$ $10^{4}$ cells per well and cultured for $24 \mathrm{~h}$. After incubation, the cells were treated for $72 \mathrm{~h}$ with various concentrations of PEC or solvent alone (control). The cells were then collected, washed with PBS, and subsequently fixed in $70 \%$ ethyl alcohol. The cells were then stained with propidium iodide (PI; $0.5 \mathrm{mg} / \mathrm{mL}$ ), supplemented with RNase A (50 mg/mL), and analyzed using flow cytometry and ModFit LT software (ver. 4.0; BD Biosciences, Franklin Lakes, NJ, USA).

\section{Determination of melanin formation}

A375 cells were seeded in 24-well plates at $2 \times$ $10^{5}$ cells per well. After culture for $24 \mathrm{~h}$, the cells were incubated with PEC or solvent for $72 \mathrm{~h}$. After washing, the cells were collected and subjected to trypsinization. The cells were then centrifuged $(700 \times g, 20 \mathrm{~min})$ to collect the supernatant for the determination of extracellular melanin. The supernatant $(1 \mathrm{~mL})$, after treatment with HEPES buffer $(0.4 \mathrm{M}, 6.8 \mathrm{pH})$ and $90 \%$ ethyl alcohol, was subjected to optical density measurements at $476 \mathrm{~nm}$. For the determination of intracellular melanin, treated cells were washed, trypsinized, and subsequently treated with $1 \mathrm{~N} \mathrm{NaOH}$. Melanogenesis was determined by the sum of the extracellular and intracellular melanin contents compared with control cells.

\section{Evaluation of tyrosinase activity}

After culture and incubation with PEC or solvent for $72 \mathrm{~h}$, cells were collected, washed twice with PBS, and subjected to trypsinization. The cells were then treated with trypan blue $(0.4 \%)$. Cell lysates were prepared by treating the cells for 30 min with a solution of Triton X-100 (1\%) in sodium phosphate buffer $(0.1 \mathrm{M}, 6.8 \mathrm{pH})$. Incubation of the lysates was performed for $4 \mathrm{~h}$ with DOPA (3, 4-dihydroxyphenylalanine) and sodium phosphate buffer. After incubation, the absorbance was recorded at $490 \mathrm{~nm}$ to measure the activity of tyrosinase as the fold increase in comparison with control cells. 


\section{Western blot analysis}

After treatment with PEC or solvent for $72 \mathrm{~h}$, the cell lines were subjected to protein extraction on ice using lysis buffer $(100 \mathrm{mM} \mathrm{NaCl}, 20 \mathrm{mM}$ Tris $\mathrm{HCl}, \mathrm{pH} 7.8$, and $0.1 \% \mathrm{NP}-40$ ). The cellular homogenates were subjected to centrifugation $\left(10,000 \mathrm{rpm}, 15 \mathrm{~min}, 4^{\circ} \mathrm{C}\right)$ to obtain the supernatant, which was stored at $-80^{\circ} \mathrm{C}$ until analysis. The total protein samples obtained were separated by $10 \%$ SDS-PAGE and then transferred electrophoretically to nitrocellulose membranes. Blockage of non-specific sites on the membranes was performed at room temperature for $1 \mathrm{~h}$ using $2 \%$ bovine serum albumin. Each membrane was incubated with primary antibodies overnight at $4{ }^{\circ} \mathrm{C}$. The primary antibodies used were anti-p-Erk 1/2 (Tyr-204), anti-p-Mek 1/2 (Ser 218/Ser 222), antimicrophthalmia related transcription factor (Mitf) $(\mathrm{N}-15)$, anti-p-cAMP-response element binding protein (CREB)-1 (Ser 133), and anti-PBG-D (A16) (all from Santa Cruz Biotechnology, Inc., Santa Cruz, CA, USA). Following incubation, the membranes were washed and then incubated for $1 \mathrm{~h}$ with horseradish peroxidase-conjugated secondary antibodies at room temperature. After washing, the blots were developed using an enhanced chemiluminescence kit (Amersham, Buckinghamshire, UK) and subjected to autoradiographic film exposure.

\section{Statistical analysis}

All data are presented as mean \pm standard deviations. SigmaStat software (SPSS-Jandel 2.0 Scientific, San Jose, CA, USA) was used for all statistical analyses. An analysis of the raw data was performed using the unpaired Student's $t$-test. Among various doses, differences were considered statistically significant at $p \leq 0.05$.

\section{RESULTS}

\section{PEC inhibited A375 and B16F10 cell proliferation}

In A375 cell cultures, the addition of PEC reduced proliferation by $12,27,36,45,63$, and $79 \%$ at $5,10,15,20,25$ and $30 \mu \mathrm{M}$, respectively (Figure 1). The proliferation of B16F10 cells was also reduced by $\mathrm{PEC}$ in a concentrationdependent manner. B16F10 cell proliferation was reduced by $9,1829,38,59$, and $72 \%$ on treatment with $5,10,15,20,25$ and $30 \mu \mathrm{M}$ PEC, respectively, after $72 \mathrm{~h}$.

\section{PEC induced cell cycle arrest in A375 and B16F10 cells}

Flow cytometry revealed that PEC increased the proportion of $A 375$ cells in $\mathrm{G} 1 / \mathrm{G} 0$ phase, with a consequent reduction in $S$ phase (Figure 2). The proportion of A375 cells treated with $30 \mu \mathrm{M}$ PEC in $\mathrm{G} 1 / \mathrm{G} 0$ phase was increased to $71.23 \%$ in comparison with $47.76 \%$ in untreated cells. In S phase, the A375 cell proportion decreased, to $11.09 \%$, on treatment with $30 \mu \mathrm{M}$ PEC, relative to $29.67 \%$ in untreated cells. In G2/M phase, the percentage of A375 cells was 15.89 and $21.46 \%$ in cultures treated with $30 \mu \mathrm{M}$ PEC and without treatment, respectively (Figure 2). Similar results were obtained with B16F10 cells (Figure 2).

\section{PEC altered Mek 1/2 activity in melanoma cells}

In A375 and B16F10 melanoma cell cultures, the addition of PEC caused a reduction in Erk phosphorylation after $72 \mathrm{~h}$ (Figure 3). The addition of $5,10,15,20,25$ and $30 \mu \mathrm{M}$ PEC to cultures of A375 cells reduced the Erk phosphorylation level in a concentrationdependent manner.

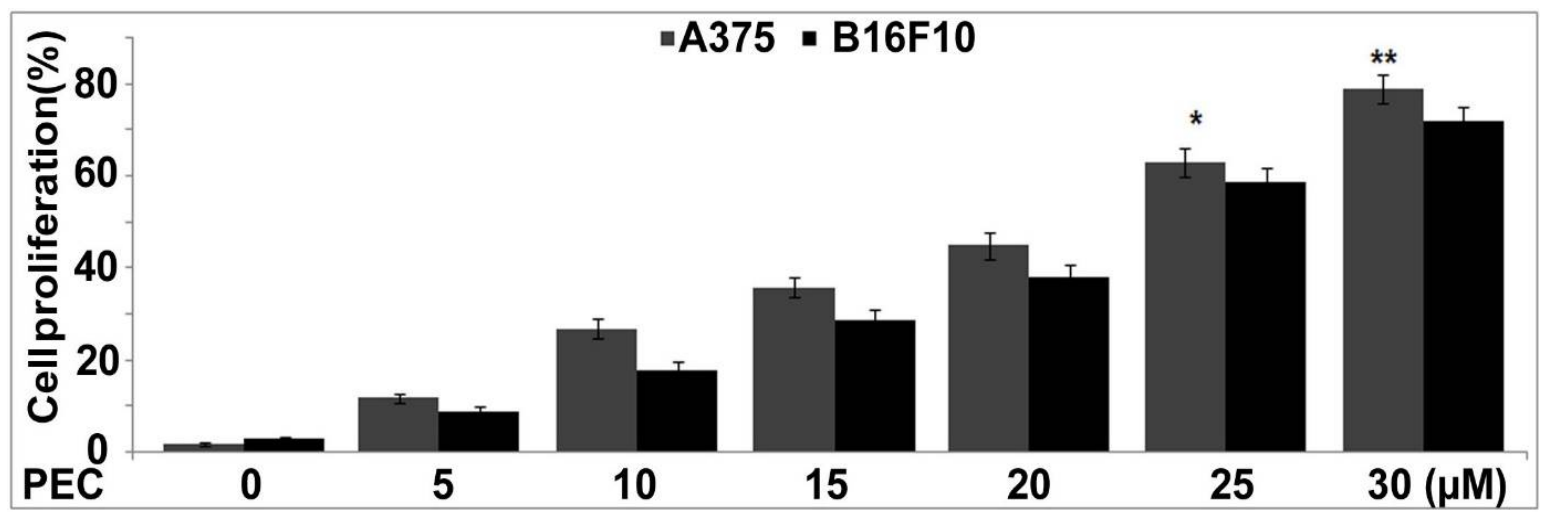

Figure 1: Effect of PEC on the rate of melanoma cell proliferation. Cells were treated with the indicated doses of $\mathrm{PEC}$ for $72 \mathrm{~h}$ followed by the determination of viability using trypan blue exclusion. The data are the means of triplicate experiments carried out independently; ${ }^{*} p<0.005$ vs. untreated cell cultures 


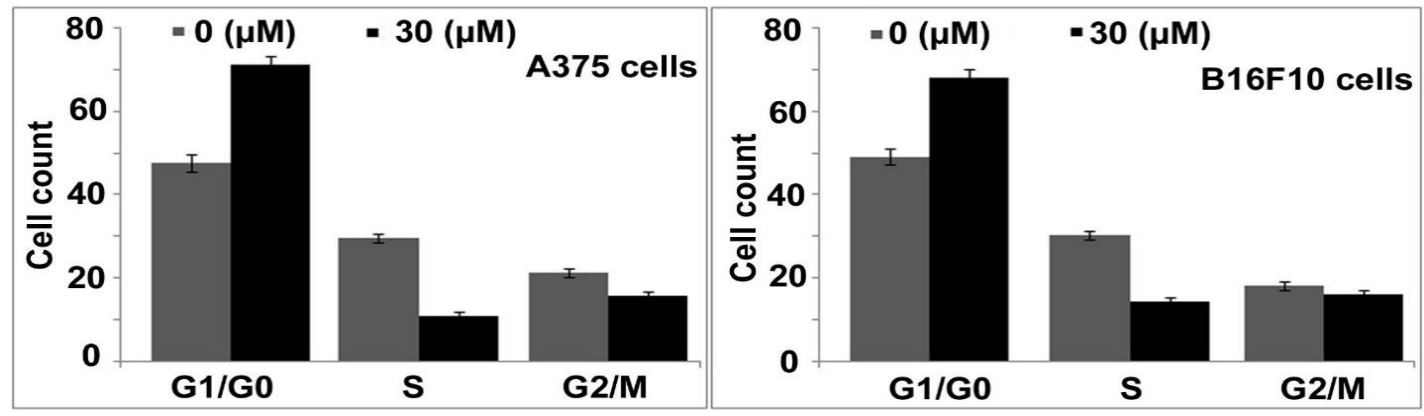

Figure 2: Effect of PEC on the cell cycle in melanoma cells. A375 and B16F10 cells were treated with PEC and then stained with $\mathrm{PI}$. The data are from triplicate experiments. ${ }^{* *} p<0.001$ vs. untreated cells
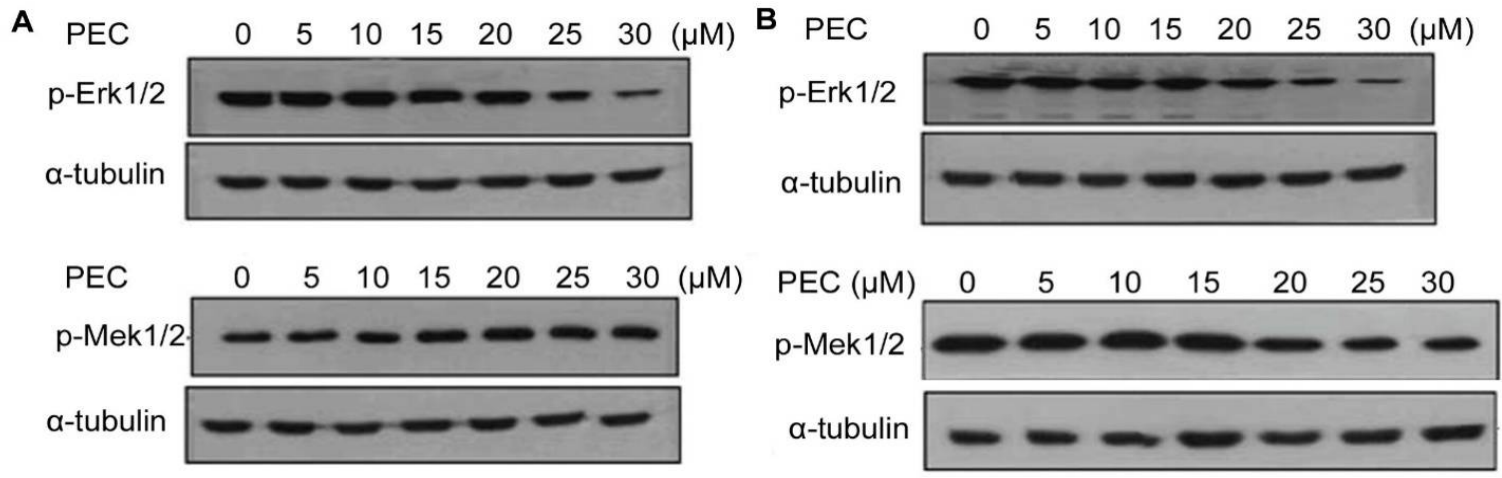

Figure 3: Effect of PEC on the phosphorylation of Erk $1 / 2$ and activation of Mek $1 / 2$ in melanoma cells. A Western blot assay was used to analyze the phosphorylation of Erk 1/2 and activation of Mek 1/2 in (A) A375 and (B) B16F10 cells after PEC treatment

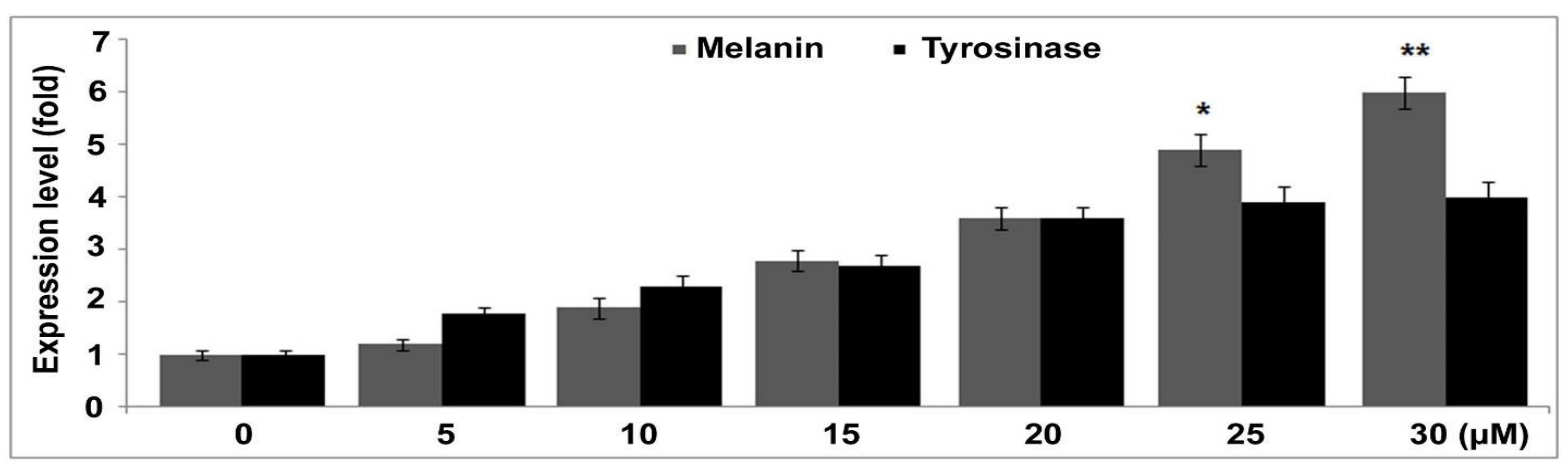

Figure 4: PEC promotes the formation of melanin and tyrosinase in $A 375$ cells. The data are the means of three independent experiments; ${ }^{*} p<0.005,{ }^{* *} p<0.005$ vs. solvent-treated cells

Similarly, in B16F10 cells, the phosphorylation level was reduced on treatment with $5,10,15$, 20, 25 and $30 \mu \mathrm{M}$ PEC. Mek 1/2 activation was promoted in both $A 375$ and B16F10 cell cultures on the addition of PEC. Densitometry revealed 8, 19, 47, 69, 72 and $91 \%$ increases in the activation level of Mek $1 / 2$ in A375 cell cultures on the addition of $5,10,15,20,25$ and $30 \mu \mathrm{M}$ PEC, respectively.

Similarly, in B16F10 cell cultures, the addition of $5,10,15,20,25$ and $30 \mu \mathrm{M}$ PEC enhanced the Mek 1/2 activation level to $6,16,43,61,74$ and $88 \%$, respectively (Figure $3 \mathrm{~A}$ and Figure $3 \mathrm{~B}$ ).

\section{PEC promoted melanogenesis in melanoma} cells

In A375 cell cultures, incubation with PEC promoted the formation of melanin at $72 \mathrm{~h}$ (Figure 4). Melanin formation was increased by $1.2,1.9,2.8,3.6,4.9$ and 6 -fold in A375 cells upon treatment with PEC at 5, 10, 15, 20, 25 and $30 \mu \mathrm{M}$, respectively. Tyrosinase activity in A375 cells was also promoted, by 1.8, 2.3, 2.7, 3.6, 3.9 and 4-fold, on treatment with 5, 10, 15, 20, 25 and $30 \mu \mathrm{M}$ PEC, respectively (Figure 4). 
PEC increased the phosphorylation of CREB and the expression of Mitf in melanoma cells

In A375 cell cultures, the addition of PEC increased the CREB phosphorylation level at 72 h. PEC addition at 5, 10, 15, 20, 25 and $30 \mu \mathrm{M}$ increased the phosphorylation of CREB in a dose-based manner versus untreated cells (Figure 5A). The level of Mitf was also increased in A375 cells on treatment with PEC for $72 \mathrm{~h}$. The increase was maximal at $30 \mu \mathrm{M}$ PEC. Similar results were observed for CREB and Mitf in B16F10 cells (Figure 5B).

\section{PEC increased the level of porphobilinogen deaminase (PBG-D) in melanoma cells}

An analysis of the expression level of PBG-D protein showed a marked increase in A375 and $\mathrm{B} 16 \mathrm{~F} 10$ cells on the addition of PEC to cell cultures at $72 \mathrm{~h}$. The level of PBG-D expression was increased, 2.0, 3.5, 4.6, 5.9, 7.6 and 9-fold, by $5,10,15,20,25$ and $30 \mu \mathrm{M}$ PEC in A375 cells, respectively (Figure 6A). Similarly, in B16F10 cells, the addition of PEC to cultures increased the level of PBG-D at 5, 10, 15, 20, 25 and $30 \mu \mathrm{M}$ by $1.9,3.1,4.4,5.3,7.4$ and 8.5 -fold, respectively (Figure 6B).

\section{U0126 promoted the PEC-mediated inhibition of $\mathrm{A} 375$ and $\mathrm{B} 16 \mathrm{~F} 10$ cell proliferation}

In A375 cell cultures, the addition of PEC reduced cell growth by $79 \%$ at $30 \mu \mathrm{M}$ (Figure 7). Addition of the Mek 1/2 inhibitor U0126 enhanced the PEC-mediated reduction in cell growth. PEC at $30 \mu \mathrm{M}$ was added to cultures of A375 cells in combination with various concentrations of U0126. At 1, 2, 4, 6, 8 and 10 $\mu \mathrm{M}$ U0126, in combination with PEC, cell viability was reduced by $83,87,89,92,93$ and $96 \%$, respectively, versus the control (Figure 7). Similar results were observed for the inhibition of B16F10 cell proliferation by U0126 treatment (Figure 7).

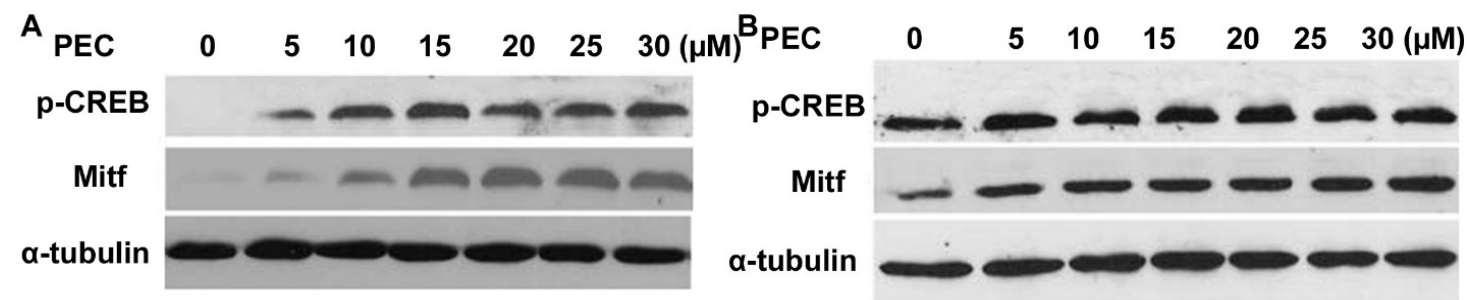

Figure 5: Effect of PEC on the phosphorylation of CREB and expression of Mitf in melanoma cells. (A) A375 and (B) B16F10 cells were treated with PEC for $72 \mathrm{~h}$ and then analyzed for changes in CREB phosphorylation and Mitf expression using Western blotting

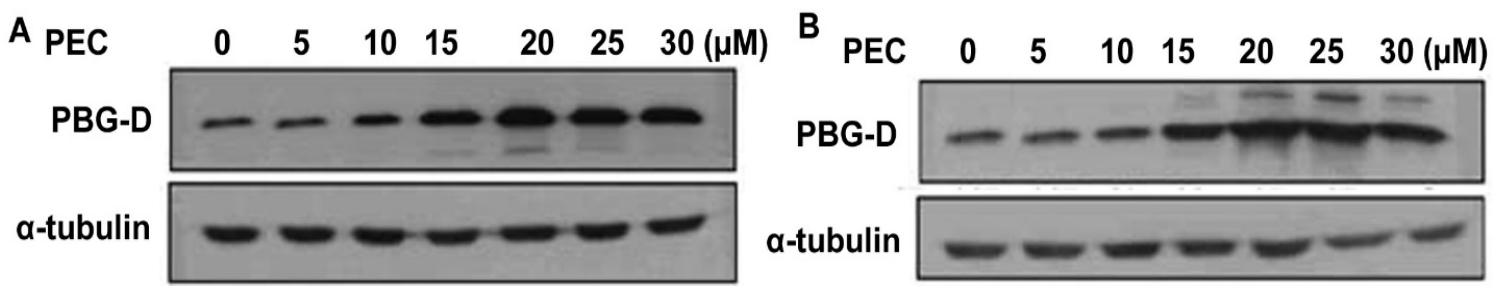

Figure 6: Effects of PEC on the PBG-D levels in melanoma cells. Cells treated with PEC were analyzed using Western blotting to assess the levels of PBG-D. $\alpha$-Tubulin was used as an internal loading control

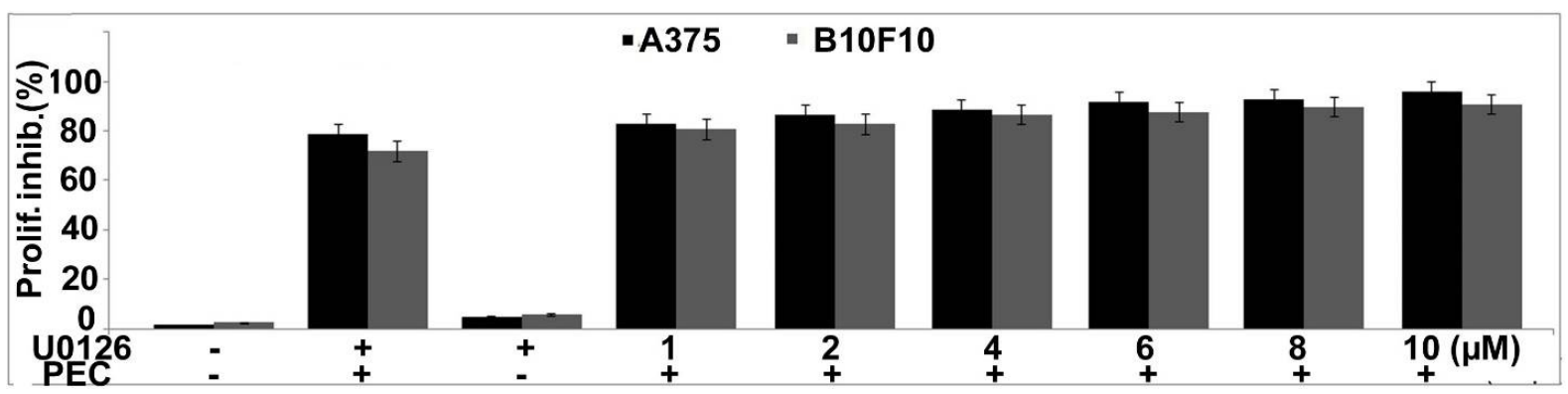

Figure 7: Effect of the Mek 1/2 inhibitor U0126 on the PEC-mediated reduction in cell growth. Cells were treated with the indicated doses of U0126 and PEC followed by an analysis of cell viability. The data are the means of triplicate independent experiments; ${ }^{*} p<0.005$ vs. untreated cell cultures 


\section{DISCUSSION}

In this study, we demonstrated the role of PEC in the inhibition of melanoma cell growth. The data show that PEC inhibited melanoma cell proliferation and blocked the cell cycle in G0/G1.

The regulation of cellular processes, including viability, proliferation, and differentiation, via the transfer of signals from the cell to the nucleus, leading to cell cycle progression at $\mathrm{G} 0 / \mathrm{G} 1$, is maintained by Erk 1/2, which belongs to the mitogen-activated protein kinase (MAPK) signaling pathway [16]. MAPK pathway regulation and Erk activation are dependent on Mek 1/2. The present study indicates that Erk phosphorylation was inhibited in melanoma cell lines upon treatment with PEC. PEC treatment also promoted the activation of Mek 1/2 in melanoma cells. Studies have shown that, among melanoma cells, more than $60 \%$ harbor an activating mutation that induces Mek and Erk activation and consequently promotes the proliferation of cells and inhibits pigmentation [17].

The current study demonstrates that PEC treatment promoted melanogenesis in melanoma cells in a dose-dependent manner. Thus, PEC promoted Mek 1/2 activation, reducing its kinase activity and leading to the upregulation of melanogenesis through a cell cycle arrest. The formation of melanin in melanoma cells is induced via cAMP [18]. The activation and translocation of protein kinase $A$, and, consequently, CREB activation and gene transcription, are due to cAMP [19]. One of the genes expressed during this process is Mitf, which plays important roles in the regulation of melanocyte viability, proliferation, and differentiation [20].

Mitf is also involved in the transcription of tyrosinase-related genes, which are involved in melanogenesis induced by cAMP [21]. In the current study, PEC treatment significantly promoted the formation of melanin and the activity of tyrosinase in melanocytes. In melanoma cell lines, the addition of PEC increased the phosphorylation level of CREB. The level of Mitf was also increased in melanoma cells on treatment with PEC. Studies have shown that Erk 1/2 activation leads to the downregulation of Mitf expression [22]. Thus, the present study shows that PEC promoted the expression of Mitf and increased the CREB level by downregulating Erk 1/2 phosphorylation. In melanoma cells, Mitf mediated melanogenesis via an arrest of the cell cycle in G1/G0 phase.
In the present study, PEC treatment inhibited the activity of Mek 1/2 kinase and phosphorylation of Erk, which play key roles in cell proliferationrelated gene transcription. Thus, it appears that PEC treatment causes stabilization of the cAMP signaling pathway in melanoma cells, phosphorylates CREB, and increases the level of Mitf, leading to the promotion of differentiation and melanogenesis. Our results show that U0126, in combination with PEC, enhanced the inhibition of melanoma cell proliferation. U0126 inhibited cell viability, promoted melanoma cell differentiation, and inhibited tumor cell invasion [23]. Major factors that mediate the Raf signaling pathway include Mek 1 and Mek 2, which are considered to be of great value for downregulating the Raf/Mek/Erk pathway in carcinomas [23]. This study thus shows that U0126 downregulated the Ras/Raf/Mek/Erk pathway, which, in turn, increased the sensitivity of melanoma cells to PEC.

\section{CONCLUSION}

PEC inhibited the proliferation of melanoma cells by blocking the cell cycle at G1/G0 phase and induced melanogenesis through Mek 1/2 activation. Thus, PEC may be useful for the induction of differentiation and melanogenesis in melanoma cells.

\section{DECLARATIONS}

\section{Acknowledgement}

Financial support from the Department of Dermatology, Union Hospital, Tongji Medical College, Huazhong University of Science and Technology, Wuhan, China, is acknowledged.

\section{Conflict of Interest}

No conflict of interest associated with this work.

\section{Contribution of Authors}

The authors declare that this work was done by the authors named in this article and all liabilities pertaining to claims relating to the content of this article will be borne by them.

\section{Open Access}

This is an Open Access article that uses a funding model which does not charge readers or their institutions for access and distributed under the terms of the Creative Commons Attribution License (http://creativecommons.org/licenses/by/ 
4.0) and the Budapest Open Access Initiative (http://www.budapestopenaccessinitiative.org/rea d), which permit unrestricted use, distribution, and reproduction in any medium, provided the original work is properly credited.

\section{REFERENCES}

1. Miller AJ, Mihm MC (Jr). Melanoma. N Engl J Med 2006; 355: 51-65.

2. Linos E, Swetter SM, Cockburn MG, Colditz GA, Clarke $C A$. Increasing burden of melanoma in the United States. J Invest Dermatol 2009; 129: 1666-1674.

3. Howlader N, Noone AM, Krapcho M, Neyman N, Aminou $R$, Waldron W, Altekruse SF, Kosary CL, Ruhl J, Tatalovich Z. SEER Cancer Statistics Review 2013; 1975-2009.

4. Bedikian AY, Millward M, Pehamberger H, Conry R, Gore M, Trefzer U, Pavlick AC, DeConti R, Hersh EM, Hersey P. Bcl-2 antisense (oblimersen sodium) plus dacarbazine in patients with advanced melanoma: The Oblimersen Melanoma Study Group. J Clin Oncol2006; 24: 4738-4345.

5. Engelman JA, Jänne PA. Mechanisms of acquired resistance to epidermal growth factor receptor tyrosine kinase inhibitors in non-small cell lung cancer. Clin Cancer Res 2008; 14: 2895-2899.

6. Hunt KJ, Hung SK, Ernst E. Botanical extracts as antiaging preparations for the skin: A systematic review. Drugs Aging 2010; 27: 973-985.

7. Antignac E, Nohynek GJ, Re T, Clouzeau J, Toutain H. Safety of botanical ingredients in personal care products/cosmetics. Food Chem Toxicol 2011; 49: 324341.

8. Arts IC. A review of the epidemiological evidence on tea, flavonoids, and lung cancer. J Nutr 2008; 138: S1561S1566.

9. Kupeli E, Sahin FP, Yesilada E, Calis I, Ezer N. In vivo antiinflammatory and antinociceptive activity evaluation of phenolic compounds from Sideritis stricta. J Biosci 2007; 62: 519-525.

10. Sobocanec S, Sverko V, Balog T. Oxidant/antioxidant properties of Croatian native propolis. J Agric Food Chem 2006; 54: 8018-8026.

11. Dhawan K, Kumar S, Sharma A. Beneficial effects of chrysin and benzoflavone on virility in 2-year-old male rats. J Med Food 2002; 5: 43-48.
12. Khoo BY, Chua SL, Balaram P. Apoptotic effects of chrysin in human cancer cell lines. Int J Mol Sci 2010; 11: 2188-2199.

13. Weng MS, Ho YS, Lin JK. Chrysin induces G1 phase cell cycle arrest in C6 glioma cells through inducing p21Waf1/Cip1 expression: involvement of p38 mitogenactivated protein kinase. Biochem Pharmacol 2005; 69: 1815-1827.

14. Hu K, Wang W, Cheng H, Pan SS, Ren J. Synthesis and cytotoxicity of novel chrysin derivatives. Med Chem Res 2011; 20: 838-846.

15. Edward M, Gold JA, Mackie RM. Different susceptibilities of melanoma cell to retinoic acid-induced changes in melanotic expression. Biochem Biophys Res Commun 1988; 155: 773-778.

16. Torii S, Yamamoto T, Tsuchiya Y, Nishida E. ERK MAP kinase in $G 1$ cell cycle progression and cancer. Cancer Sci 2006; 97: 697-702.

17. Wellbrock C, Marais R. Elevated expression of MITF counteracts B-RAF-stimulated melanocyte and melanoma cell proliferation. J Cell Biol 2005; 170: 703708.

18. Costin G-E, Hearing VJ. Human skin pigmentation: melanocytes modulate skin color in response to stress. FASEB J 2007; 21: 976-994.

19. Kadekaro AL, Kavanagh RJ, Wakamatsu K, Ito $S$, Pipitone MA, Abdel-Malek ZA. Cutaneous photobiology. The melanocyte vs. the sun: who will win the final round? Pigment Cell Res 2003; 16: 434-447.

20. Mansky KC, Sankar U, Han J, Ostrowski MC. Microphthalmia transcription factor is a target of the p38 MAPK pathway in response to receptor activator of NFkappa B ligand signaling. J Biol Chem 2002; 277: 11077-11083.

21. Vance KW, Goding CR. The transcription network regulating melanocyte development and melanoma. Pigment Cell Res 2004; 17: 318-325.

22. Hemesath TJ, Price ER, Takemoto C, Badalian T, Fisher $D E$. MAP kinase links the transcription factor microphtalmia to c-Kit signalling in melanocytes. Nature 1998; 391: 298-301.

23. Namkoong J, Martino JJ, Chen S. From existing therapies to novel targets: a current view on melanoma. Front Biosci 2006; 11: 2081-2092. 